\title{
Pharmaceutical Significance of Nigella Sativa L., a Wonder Herb
}

\author{
Irfat Ara ${ }^{1}$, Mudasir Maqbool $^{2 *}$, Ginenus Fekadu ${ }^{3}$, Tawseef Ahmad Hajam², Mohmad Amin Dar ${ }^{2}$
}

\begin{abstract}
Nigella sativa L. (Family: Ranunculaceae; commonly known as black cumin) is an annual herb. N. sativa is cultivated and distributed all over India, especially in Punjab, Himachal Pradesh, Gangetic plains, Bihar, Bengal, Assam and Maharashtra. Among the traditional remedies, prescriptions of Nigella sativa for the treatment of various diseases are well-known since the prehistoric era. Therapeutic effects of Nigella sativa are thought to be due to nigellone and thymoquinone contents. The reported pharmacological properties include protection against disease and chemical-induced renal and hepatic toxicity, anti-inflammatory, analgesic, antipyretic, antimicrobial and antineoplastic activities. The oil decreases blood pressure, cholesterol, triglycerides, and glucose and increases respiration, hemoglobin and packed cell volume. In the traditional system of medicine, black cumin seeds are effective against cough, bronchitis, asthma, chronic headache, migraine, dizziness, chest congestion, dysmenorrheal, obesity, diabetes, paralysis, hemiplegia, back pain, infection, inflammation, rheumatism, hypertension and gastrointestinal problems such as dyspepsia, flatulence, dysentery, and diarrhea. In this review, we will elaborate about this wonder herb having miraculous effects.
\end{abstract}

Keywords: Anti-diabetic activity, Anti-microbial activity, Black cumin, Phytochemicals, Thymoquinone.

Journal of Applied Pharmaceutical Sciences and Research, (2020); DOI: 10.31069/japsr.v3i4.2

\section{INTRODUCTION}

Ever since ancient times, the drugs delivered from the plant kingdom are used to alleviate or to cure human diseases. The indigenous system of medicine is gradually gaining popularity mainly because of less or no toxic or side effect of herbal drugs. ${ }^{[1]}$ Simultaneously, researchers have developed a growing interest for traditional remedies used by ancient tribes and old civilizations. It is believed that investigation of such ancient drugs on scientific line with modern scientific appliances and methodologies may unravel a vast number of effective remedies for treating diseases and alleviating human sufferings. The inventory of medicinal plants, their availability and uses started as early as 3,500 BC or even prior to that in Indian, Egyptian and Chinese civilization. It is estimated that about 2,50,000 to 5,00,000 plant species present on earth possess medicinal properties and are used to curate a number of disorders. In most of Asia, traditional medicinal plants are part of a culture and it is passed through the generations and hence promoting the use of the medicinal plant for health purposes. ${ }^{[1]}$ Nigella sativa $\mathrm{L}$. (Family: Ranunculaceae; commonly known as black cumin) is an annual herb possessing a wide range of medicinal uses notwithstanding its commercial significance as a spiceyielding plant. ${ }^{[2-5]}$

\section{Nigella Sativa}

\author{
Scientific Blassification ${ }^{[6-9]}$ \\ Kingdom: Plantae. \\ Division: Angiosperms. \\ Class: Eudicots. \\ Order: Ranuculales.
}

${ }^{1}$ Regional Research Institute of Unani Medicine Hazratbal Srinagar-190006, Jammu and Kashmir, India

${ }^{2}$ Department of Pharmaceutical Sciences, University of Kashmir, Hazratbal Srinagar-190006, Jammu and Kashmir, India

${ }^{3}$ Department of Pharmacy, Institute of Health Science, Wollega University, Nekemte, Ethiopia

Corresponding Author: Mudasir Maqbool, Department of Pharmaceutical Sciences, University of Kashmir, Hazratbal Srinagar-190006, Jammu and Kashmir, India, Email: bhatmudasir92 @gmail.com

How to cite this article: Ara I, Maqbool M, Fekadu G, Hajam TA, Dar MA. Pharmaceutical Significance of Nigella Sativa L., a Wonder Herb. Journal of Applied Pharmaceutical Sciences and Research. 2020; 3(4):4-13

Source of support: Nil

Conflict of interest: None

Family: Ranuculaceae.

Genus: Nigella.

Species: Nigella Sativa.

\section{Common Names ${ }^{[6-9]}$}

English: Black-caraway, Black-cumin, Fennel-flower, Romancoriander.

Hindi: Kalonji, Kalajira.

Sanskrit: Mugrela, Upakuncika, Kalajaji.

Kannada: Kari jirige.

Bengali: Kalo jira.

Among the traditional remedies, prescriptions of Nigella sativa for the treatment of various diseases are well-known since the prehistoric era and especially its seeds for over 4000 years all over world. ${ }^{[10]}$ It is commonly known as black seed or black cumin. The pre-Islamic Arabian world knew the

(-The Author(s). 2020 Open Access This article is distributed under the terms of the Creative Commons Attribution-NonCommercial-ShareAlike 4.0 International (CC BY-NC-SA 4.0) (https://creativecommons.org/licenses/by-nc-sa/4.0/) 
seed well, as the Egyptians used to keep the black seeds with mummies in their tombs, thinking that it would help them in the life thereafter. This indicates that Nigella sativa was used by Egyptians in different walks of their lives. The Holy Prophet Muhammad (PBUH) appreciated the use of black seed to remedy every illness except the death (Figures 1 and 2). ${ }^{[1]}$

\section{Morphological Features of Nigella sativa}

Nigella sativa is a pretty erect herb, $30-60 \mathrm{~cm}$ high. Its leaves are alternate and bipinnately dissected. The stipules are small. The flowers are terminal, pedunculated and whitish blue or purplish in color. Sepals are five, regular, deciduous, imbricate, and petaloid. Petals are five with long claws and small bifid limbs. Stamens are numerous. Carpals are 3-10, sessile, connate below and, each with several horizontal ovules. Two seriates on the suture and style is usually long. The fruit is a capsule, dehiscing along ventral suture of a free portion of individual carpal. Dried fruit and seeds are the main plant components and are mostly used medically. Seeds of Nigella sativa are black in color and triangular in shape. The seed is

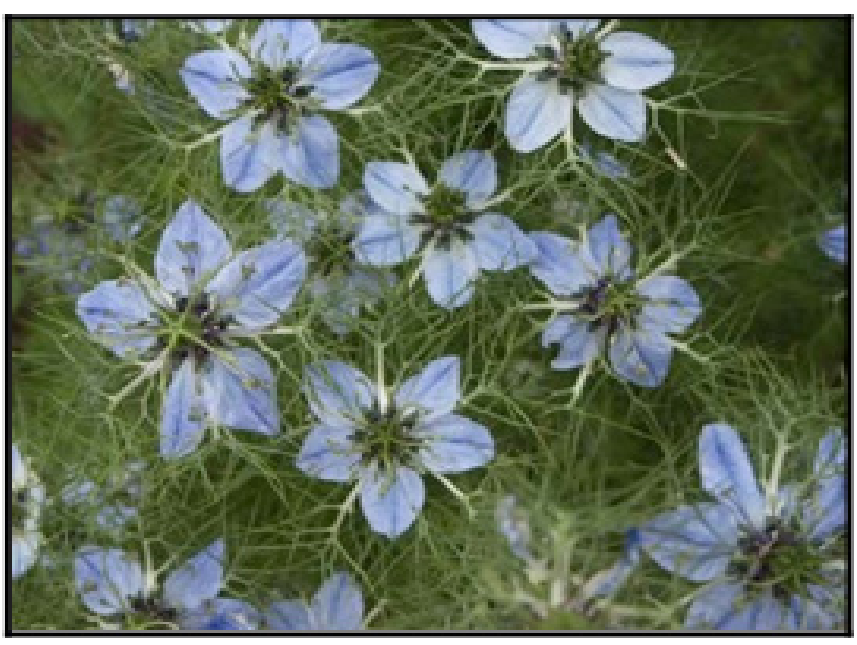

Figure 1: $N$. sativa flower ${ }^{[6-12]}$

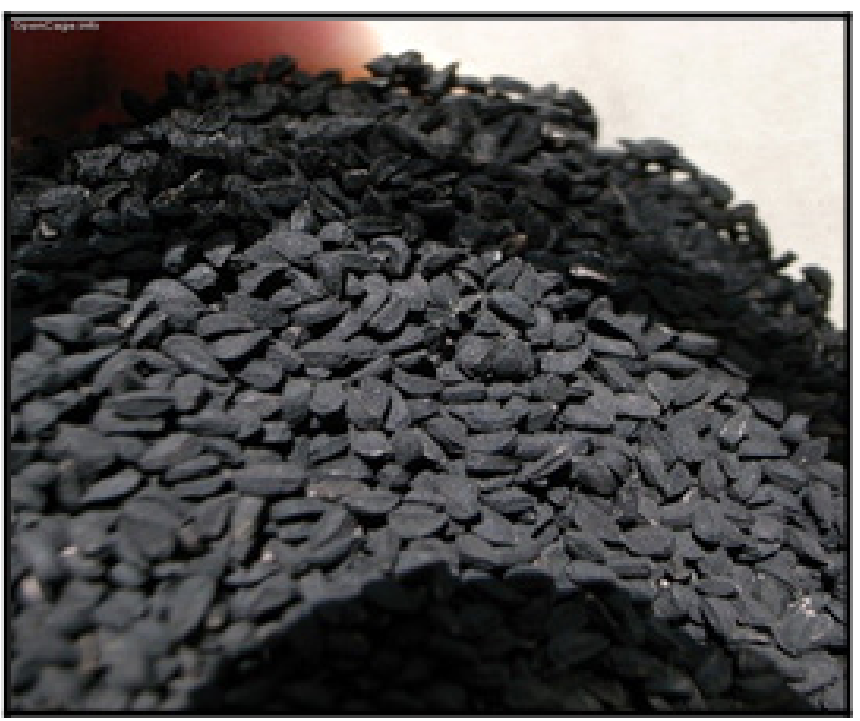

Figure 2: $N$. sativa seeds ${ }^{[6-12]}$ about one-eighth inch long having a rough interior and a white oily kernel. On rubbing, the seed diffuses a pleasant odor of lemon with a slight soupcon of carrot. ${ }^{[12]}$

\section{Geographical Distribution of Nigella sativa}

N. sativa is cultivated and distributed all over India, especially in Punjab, Himachal Pradesh, Gangetic plains, Bihar, Bengal, Assam, and Maharashtra. ${ }^{[5]}$ Apart from India, the species is also grown in Syria, Lebanon, Israel and South Europe, and Bangladesh, Turkey, Middle-East and the Mediterranean basin. ${ }^{[13,14]}$ The species grows well in cool-dry to warm-humid areas. Cool and humid weather favors flowering and seed set. The species is grown once in a year during rabi season in any good soil from October to November in plains and from April to the end of May in hills, and yield per acre is not satisfactory. ${ }^{[15]}$ The yield of black cumin seeds has been reported to be 8.13

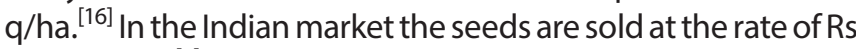
$250-300 / \mathrm{Kg}^{[5]}$ It is reported that the species is highly suitable for cultivation by marginal farmers. Although a native place of Nigella sativa is not exactly known, this herbaceous plant belongs to countries around the Mediterranean Sea like Egypt, Turkey and Italy. ${ }^{[17]}$ Roxburgh believes this plant to be a native of India so also called as Nigella indica. ${ }^{[18]}$

\section{Phytochemicals of Nigella sativa}

According to Ahmed Aftab et al, many active compounds have been isolated, identified and reported in different varieties of black seeds. The most important active compounds are thymohydroquinone, dithymoquinone, thymoquinone (30\%-48\%), 4-terpineol (2\%-7\%), sesquiterpene longifolene (1\%-8\%) a-pinene, t-anethol (1\%-4\%), p-cymene (7\%-15\%), carvacrol (6\%-12\%) and thymol etc. ${ }^{[19]}$ Black seeds also contain some other compounds in traces. These contain two different types of alkaloids; isoquinoline alkaloids like nigellicimine$\mathrm{N}$-oxide and nigellicimine and indazole ring bearing alkaloids or pyrazol alkaloids like nigellicine and nigellidine. The seeds also contain alpha-hederin, a water-soluble pentacyclic triterpene and saponin, a potential anticancer agent. ${ }^{[19,20]}$ Other compounds like carvone, limonene, and citronellol are also found in traces. Most of the pharmacological properties of Nigella sativa are mainly due to quinine constituents, out of which thymoquinone is the most important quinine constituent and main reason behind the medicinal properties of the seed. On storage, thymoquinone yields dithymoquinone and higher oligocondensation products. The seeds of Nigella sativa contain protein $(26.7 \%)$, fat (28.5\%), carbohydrates (24.9\%), crude fibre (8.4\%) and total ash (4.8\%). Various vitamins and minerals like $\mathrm{Cu}, \mathrm{P}, \mathrm{Zn}$ and Fe also contents of Nigella sativa seed in good amount. The seeds contain carotene which is converted by the liver to vitamin A. Root and shoot are reported to contain vanillic acid. ${ }^{[21]}$ Many previous studies reported that the Nigella sativa seeds to contain a fatty oil rich in unsaturated fatty acids, mainly linoleic acid, eicodadienoic acid, oleic acid, and dihomolinoleic acid. In Nigella sativa seed saturated fatty acids also present about $30 \%$ or less. a-sitosterol is a major 
sterol that accounts for around $55 \%$ of the total sterols of black seed and stigmasterol one of the major sterol after a-sitosterol. ${ }^{[22,23]}$ In some studies, it is reported that the other components includes nigellone, avenasterol-5-ene, avenasterol-7-ene , camp esterol, cholesterol , citrostadieno I, cycloeucalenol, gramisterol, lophenol, obtusifoliol, stigmastanol, stigmasterol-7-ene, $\beta$-amyrin, butyro-spermol, cycloartenol, 24-methylenecycloartanol, taraxerol, tirucallol, volatile oil (0.5-1.6\%), fatty oil (35.6-41.6\%), oleic acid, esters of unsaturated fatty acids with C15 and higher terpenoids, esters of dehydrosteari, hederagenin glycoside, aliphatic alcohol, linoleic acid, melanthin, melanthigenin, $\beta$-unsaturated hydroxy ketone, tannin, resin, reducing sugar, glycosidal saponin and protein. ${ }^{[24-26]}$

\section{Nutritional Value of Nigella sativa}

The earlier studies have shown Nigella sativa to have a high nutritional potential i.e., protein (22\%), fat (38-40\%) and carbohydrates $(32 \%) .{ }^{[27,28]}$ The mineral and vitamin contents per kg seeds are iron (105 rag), copper (18 rag), zinc (60 mg), phosphorus (527 rag), calcium (1860 rag), thiamin (15.4 rag), niacin (57 mg), pyridoxine (5.0 rag) and folic acid (160 pg). ${ }^{[29,30]}$ A qualitative study of Nigella sativa and a number of other plant extracts of Saudi origin used in folk medicine has revealed the presence of sterols, triterpenes, tannins, flavonoids, cardiac glycosides, alkaloids, saponins, volatile oils, coumarins, volatile bases, glucosinolates and anthraquinones. ${ }^{[31]}$

\section{Pharmaceutical Significance of Phytochemicals of Nigella sativa}

In traditional system of medicine, black cumin seeds are effective against cough, bronchitis, asthma, chronic headache, migraine, dizziness, chest congestion, dysmenorrheal, obesity, diabetes, paralysis, hemiplegia, back pain, infection, inflammation, rheumatism, hypertension and gastrointestinal problems such as dyspepsia, flatulence, dysentery, and diarrhea. ${ }^{[32]}$ It has also been used as a stimulant, diuretic, emmenagogue, lactagogue, anthelmintic and carminative, and applied to abscesses, nasal ulcers, orchitis, eczema and swollen joints. ${ }^{[33]}$ Seed oil is considered to be local anesthetic. ${ }^{[34-35]}$ The species possesses anti-microbial activity. Diethyl ether, methanol, chlorophyll and total plant extracts as well as seed oil was found to inhibit Staphylococcus aureus, Pseudomonas aeruginosa, Escherichia coli and a pathogenic yeast Candida albicans, ${ }^{[36-39]}$ anti-malarial, ${ }^{[40]}$ antioxidant (thymoquinine constituent of seed oil enhance the oxidant scavenging system, anti-inflammatory (the oil and thymoquinone); ${ }^{[41]}$ thymoquinone has the ability to attenuate allergic airway inflammation by inhibiting Th2 cytokines and eosinophil infiltration into the airways and exploratory effects, ${ }^{[42]}$ anti-cancerous methanolic extract of plant exhibits potent inhibition of cancerous cell growth against $\mathrm{HL}-60$ and $\mathrm{U}-937$ cell lines with IC50 value 13.50 $\mu \mathrm{g} / \mathrm{mL}$ and $28.31 \mu \mathrm{g} / \mathrm{mL}$ respectively, ${ }^{[43]}$ antitumerogenic, ${ }^{[44]}$ anti-hypertensive, ${ }^{[45]}$ antiviral, ${ }^{[45]}$ anti-asthmatic (crude seed extracts exhibits spasmolytic and bronchodilator activities mediated possibly through calcium channel blockade), ${ }^{[46]}$ anti-allergic (oil is an important adjuvant for the treatment of allergic disease), ${ }^{[47]}$ anti-diabetic, antilipidemic, antiobesity, ${ }^{[15]}$ anticonvulsant, ${ }^{[48,49]}$ antitoxic ${ }^{[50]}$ properties apart from having immunomodulatory (extract inhibit human neutrophil elastase activity which is mainly attributed to carvacrol), ${ }^{[51]}$ hematological (oil play role in modulating the balance of fibrinolysis/thrombus formation by modulating the fibrinolytic potential of endothelial cells), ${ }^{[52,53]}$ gastroprotective (thymoquinone protect gastric mucosa against injurious effect of absolute alcohol and promote ulcer healing) ${ }_{1}^{[15]}$ nephroprotective ${ }^{[54-56]}$ diuretic ${ }_{,}^{[57]}$ cardiovascular (active ingredient thymol has shown to lower blood pressure through blockade of calcium channels) ${ }^{[52]}$ properties. The species is protective against heavy metal, ${ }^{[58,59]}$ effects nitric acid production ${ }^{[60]}$ and also possesses analgesic activity. ${ }^{[61]}$ Moreover, essential oil was found to be effective against $\mathrm{Cr}(\mathrm{VI})$ hazard and may be a promising candidate against different environmental pollutants. ${ }^{[62,63]}$ Tasawar et al. (2011) reported that black cumin (tested on 80 subjects, divided randomly into 2 groups) is effective in changing the lipid profile significantly in a way that is beneficial to heart. N. sativa is also a potential source for antidermaphytic drugs. The ether extract of seeds and its active principle thymoquinone are found to be effective against many species of three important genera of dermatophytes: Trichophyton, Epidemophyton and Microsporum. ${ }^{[64,65]}$ The volatile oil inhibited the spontaneous movements of rat and guinea pig uterine smooth muscle and also the contraction-induced oxytocin suggesting its antioxytocic potential. ${ }^{[50]}$ Hot water extract of N. sativa, as well as whole seeds in large oral doses, causes abortion in human pregnant females. ${ }^{[6]}$ Thymoquinone has been reported to exhibit effect on dopaminergic neurons against Parkinson's disease. ${ }^{[67]}$ The species also possesses insecticidal activity. An essential oil from dried fruits was isolated by hydrodistillation and tested for its repellent, toxic and developmental inhibitory activities against wheat flour pest Tribolium castaneum. Seed cakes of $N$. sativa in the feed of buffalo and lambs improved their body weight and reproductivity as well as seeds in the food of broiler chicks improved their immunity and feed conversion. ${ }^{[67-70]}$ Some significant pharmaceutical properties of $N$. sativa are mentioned below:

\section{Anti-microbial Action}

Studies revealed that the oil of $N$. sativa has impressive antibacterial activity. ${ }^{[36]}$ The study showed the extract successfully eradicated a non-fatal subcutaneous staphylococcal infection in mice. The oil proved to be more effective against many bacteria strains, including those known to be highly resistant to drugs. ${ }^{[71]}$ The essential oil has been shown to have activity against Gram-positive and Gram-negative bacteria both. However, activity against Gram-positive bacteria such as Staphylococcus aureus and Vibrio cholerae was found to be stronger. ${ }^{[72]}$ Bacteria like Staphylococcus aureus, S. pyogenes 
and S. viridans are more susceptible to its oil. Anti-bacterial activity of $N$. sativa is said to be due to thymoquinone, which prevent bacterial biofilm formation and show anti-bacterial effect on pathogenic bacteria at low concentrations of 8-32 $\mu \mathrm{g} / \mathrm{mL}{ }^{\left[{ }^{38]}\right.}$ In vitro studies have also revealed its moderate antifungal activity on growth of pathogenic fungi. ${ }^{[71,73]}$ The in vivo studies also supported that the aqueous extract from $N$. sativa seeds exhibits inhibitory effect against fungal infections. $^{[74]}$

Khan et. al, (2003) studied the effect of aqueous extract of $N$. sativa seeds on candidiasis in mice. An intravenous inoculum of Candida albicans formed colonies of the organism in the spleen, kidneys and liver. Treatment of mice with the plant extract $(6.6 \mathrm{~mL} / \mathrm{kg}$ equivalent to $5 \mathrm{mg}$ of estimated protein, once daily for 3 days) 24 hours after the inoculation, started a considerable inhibitory effects on the development of the pathogen in all organs considered. A 5-fold decrease in Candida in kidneys, 8-fold in liver and 11-fold in spleen was observed in the group of animals post-treated with the plant extract. Histopathological examination of the respective organs confirmed these findings. These results indicate that the aqueous extract of $N$. sativa seeds shows inhibitory result against candidiasis and this study confirms the traditional use of $N$. sativa seeds in fungal infections.

\section{Hepatoprotective Action}

$N$. sativa is found to have a hepatoprotective effect. This is due to its active phytochemicals thymoquinone. According to Mohideen et al. (2003), ${ }^{[75]}$ it possesses significant hepatoprotective activity against carbon tetrachlorideinduced toxicity on the liver of male Wistar rats. In another study on rabbit's model, the effect of $N$. sativa against carbon tetrachloride-induced acute liver injury showed significant hepatoprotective activity. ${ }^{[76]}$ Phytochemical and biological investigation of N. sativa L. seed waste extracts has also found it to have a promising hepatoprotective effect. ${ }^{[77]}$

$N$. sativa also attenuates the side effects associated with some common medications used by gastroenterologists. Cyclosporine, used by gastroenterologists for disorders such as recalcitrant Crohn's disease, is often associated with nephrotoxic side effects, which $\mathrm{N}$. sativa can limit due to its antioxidant properties. ${ }^{[55]}$ Similarly, N. sativa administration protects hepatic tissue from deleterious effects of toxic metals such as lead and reduces hepatic lipid peroxidation. ${ }^{[78]}$ Hepatoprotective effect of $N$. sativa oil on carbon tetrachloride-induced liver toxicity in adult wistar rats was studied by Danladi et al. (2013), which showed N. sativa decreased lipid peroxidation and liver enzymes and increased antioxidant defense system activity in the $\mathrm{CCl} 4$-treated rats. ${ }^{[79]}$ Turkdogan et al. (2003) observed that $N$. sativa has a significant hepatoprotective effect in CCl4-administrated rabbits. It was also found that $N$. sativa can prevent liver fibrosis and cirrhosis, suggesting that $N$. sativa protects liver against fibrosis possibly through immunomodulatory and antioxidant activities. ${ }^{[80]}$

\section{Anti-diabetic Action}

Many studies have been conducted to see hypoglycemic effect of $N$. sativa and thymoquinone. In a study Murli et al. (2011) showed positive results in streptozotocin (STZ) induced diabetic rats. Aqueous extract of $N$. sativa seeds causes gradual partial regeneration of pancreatic $\beta$-cells, rise in the serum insulin concentrations and reduction in the elevated serum glucose ${ }^{[81]}$ In another study a plant mixture, which contained N. sativa, produced a strong hypoglycemic effect in STZ diabetic rats. ${ }^{[82]}$ The hypoglycemic effect of the plant causes a decrease in glucogenesis. Another group of researchers using extra plant mixture, which comprises $\mathrm{N}$. sativa, stated the noteworthy glucose-lowering effect. ${ }^{[83]}$ Intragastric $N$. sativa oil administration to nicotinamideinduced diabetic hamster (400 mg/kg/day dose) showed a substantial decline in blood glucose and increase in insulin. Oral administration $(500 \mathrm{mg} / \mathrm{kg})$ of $N$. sativa oil to STZ diabetic rats reduced fasting blood glucose expressively, without any change in insulin level. ${ }^{[84]}$

\section{Anti-inflammatory and Analgesic Action}

The $N$. sativa seed oil and its phytochemical thymoquinone have been found to have a potent anti-inflammatory effect. ${ }^{[13]}$ Another compound, nigellone, inhibits the histamine release from the mast cells at low concentration, supporting the plant's anti-asthmatic role. Effects of its seed extract exhibited good anti-inflammatory and proapoptotic effects in pancreatic cancer cells. ${ }^{[85]}$

In the study by Alemi et al., (2012) ${ }^{[86]}$ the aqueous extract of $N$. sativa was found to possess anti-inflammatory and analgesic activities in animal models. The anti-inflammatory effect of the alcoholic extracts of $N$. sativa seeds and its callus on mix glial cells of rat with regard to their thymoquinone content was investigated. Inflamed by lipopolysaccharide, the mixed glial cells were exposed to anti-inflammatory studies in the presence of mutable quantities of thymoquinone and the alcoholic extracts. Results confirmed that thymoquinine content of the callus of leaf was 12 times higher than that measured in the seeds extract. A real-time polymerase chain reaction analyzed the effect of thymoquinone $(25-75 \mu \mathrm{M})$ on the expression of different pro-inflammatory cytokines and chemokines. Thymoquinone has been found to significantly reduce pancreatic ductal adenocarcinoma cell synthesis of monocyte chemoattractant protein-1, tumour necrosis factor-alpha, interleukin (IL)-1 $\beta$, and cyclooxiygenase-2 in time and day dependent manner. At 24 hours, thymoquinone almost completely abolished the expression of these cytokines. Thymoquinone also increased p21WAF1 and was found to have inhibited histone deacetylases activity, and induced histone hyperacetylation. Histone deacetylases inhibitors have been shown to ameliorate inflammationassociated cancer. Thymoquinone as a novel inhibitor of pro-inflammatory pathways delivers a hopeful approach that associate anti-inflammatory and proapoptotic modes of action. ${ }^{[85]}$ Thymoquinone exhibit a slight inhibitory effect 
on cyclooxiygenase-1 expression and prostaglandins-E2 production in a mouse model of allergic airway inflammation. This finding suggests that thymoquinone has an antiinflammatory effect during the allergic response in the lung, through the inhibition of prostaglandins-D2 synthesis and T helper cells-2 driven immune response. ${ }^{[87]}$ The hexane fraction of $\mathrm{N}$. sativa seeds' methanol extract revealed substantial anti-inflammatory activity by inhibiting nitric oxide release in lipopolysaccharide-stimulated RAW 264.7 macrophages, with an IC50 value of $6.20 \mu \mathrm{g} / \mathrm{mL}$ (Pichette et al, 2012). ${ }^{[88-90]}$ A clinical trial study was conducted as prospective and double blind with descriptive analytic to investigate the antiinflammatory property of $N$. sativa in patients with symptoms of allergic rhinitis. 66 patients (placebo and case) with allergic rhinitis were involved and exposed to $N$. sativa oil. Individual appearances, including sex and age, and characteristics of the disease, including sneezing attack, running nose, nose itching, and nasal blocking, were evaluated for 30 days. The results showed that $N$. sativa could decrease the mucosal congestion in the nose, itching in nose, running nose, sneezing attacks, turbinate hypertrophy, and mucosal pallor during the first 2 weeks (day 15). The anti-allergic effects of $N$. sativa components could be utilized against allergic rhinitis. Moreover, N. sativa should be considered for treating allergic rhinitis when the effects of other anti-allergic drugs need to be avoided. ${ }^{[91]}$ An analgesic (also known as a painkiller) is any member of the group of drugs used to relieve pain. Analgesic drugs act in various ways on the peripheral and central nervous systems. ${ }^{[92]}$ The pain relief, induced by analgesics, occurs either by obstructing pain signals reaching the brain or interfering with the brain's elucidation of the signals, deprived of making anesthesia or loss of consciousness. $N$. sativa essential oil extract thymoquinone works as a potent analgesic. $N$. sativa seeds extract on experimentally prompted pain in albino mice holds good analgesic results. ${ }^{[93]}$

\section{Antifertility Action}

Antifertility activity of $N$. sativa provoked significant modification of the veginal smear of the drug-treated rats. The estrous cycle so modified was characterized by prolonged diestrous and proestrous stage with consequent temporary inhibition of ovulation. Post-coital contraceptive efficacy of the hexane extract of seeds of $N$. sativa in rats was observed and found satisfactory. ${ }^{[94,95]}$ In the study hexane extract of the seeds of $N$. sativa L. prevented pregnancy in Sprague-Dawley rats treated orally at $2 \mathrm{~g} / \mathrm{kg}$ daily dose on days 1-10 post-coitum. Substantial antifertility action was detected in its column fractions and subfractions. At contraceptive dose, the active hexane extract showed only mild uterotrophic activity, equivalent almost to $0.002 \mathrm{mg} / \mathrm{kg}$ dose of 17 varies. It is directly related to Ethinylestradiol but was lacking in any estrogenicity in the immature rat bioassay. Thymoquinone from $N$. sativa is responsible for many of the pharmacodynamic effects. ${ }^{[96]}$

\section{Anthelmintic Action}

Anthelmintics or antihelminthics are drugs that expel parasitic worms (helminths) from the body, by either stunning or killing them. They may also be called vermifuges (stunning) or vermicides (killing). ${ }^{[97]} N$. sativa holds good anthelmintic property. Larvicidal activity has been reported against Culex pipiens when ether extract is used at 151.7 ppm. ${ }^{\text {[98] }}$

\section{Antioxidant Action}

$N$. sativa has been reported to possess significant antioxidant activity. ${ }^{[99]}$ An active component of $N$. sativa L. thymoquinone (lipophylic) exhibits a structural resemblance with the natural mitochondrial electron carrier, ubiquinone. It is of interest whether the suggested antioxidant effect of thymoquinone in cells can be explained by its interaction with the mitochondrial respiratory chain. Antioxidant Effects of $N$. Sativa in the treatment of experimentally induced rhinosinusitis revealed its role in scavenging reactive oxygen species. ${ }^{[100]}$ It was suggested that dietary supplementation of black seeds powder inhibits the oxidative stress caused by corn oil (oxidized) in rats. ${ }^{[101]}$ It was also reported that oral feeding of the diet containing black seed powder at $10 \%$ level antagonized the oxidative stress induced by hepato-carcinogens like dibutylamine and Sodium Nitrate in Swiss albino rats, by normalizing GSH and NO levels (Gendy et al, 2012). ${ }^{[102]}$ The black seed oil and thymoquinone by intraperitoneal injection were found to exhibit protective effects on lipid peroxidation process during an ischemicreperfusion injury in rat hippocampus. ${ }^{[36]}$ When treated with N. sativa for 6 weeks, broiler chicks protected the liver from oxidative stress by raising the activities of enzymes such as myeloperoxidase, glutathione-S-transferase catalase, adenosine deaminase, and by decreasing hepatic lipid peroxidation. ${ }^{[103]}$ The crude methanolic extract of $N$. sativa seed cake was found to show significant antioxidant properties under in vitro systems. ${ }^{[104]}$ The modulatory effect of thymoquinone on erythrocyte lipid peroxidation and antioxidant status during 1,2-dimethylhydrazine- (DMH-) induced colon carcinogenesis (after initiation in male Wistar rats) was investigated. It was found that thymoquinone pretreatment restored the increased level of malondialdehyde and conjugated diene levels, and augmentation of enzyme activities like catalase, glutathione peroxidase, and superoxide dismutase was noted. Thymoquinone was a useful compound in preventing $\mathrm{DMH}$-induced erythrocyte damages. ${ }^{[105]}$

\section{Anti-cancerous Action}

Potential of $N$. sativa has been explored for its anti-cancerous activity. ${ }^{[106,107]}$ Ait Mbarek et al., (2007) has worked to investigate into the anti-tumor properties of $N$. sativa extracts and found positive results. ${ }^{[108]}$ Similarly, good anti-tumor activity was found by Musa et al., (2004). ${ }^{[109]}$ The anti-cancerous property of $N$. sativa is attributed to its phytochemical thymoquinone. Apart from thymoquinone, flavonoids do have a preventive role in cancer therapy via 
the effect on signal transduction in cell proliferation. ${ }^{[110,111]}$ It has also been reported that many such antioxidants can inhibit cancer cells' proliferation. Ivankovic et. al, (2006) by an extensive study, reported the effect of thymoquinone in in-vitro experiments, using L929 mouse fibroblasts and two tumor cell lines (squamous cell carcinoma (SCC VII) and fibrosarcoma (FsaR). The cells were cultured with 0.1 or $0.01 \mathrm{mg} / \mathrm{ml}$ thymoquinone or thymohydroquinone (phytochemicals of N. sativa) for 24 hours, and cytotoxicity assay was performed. For in vivo anti-tumor efficiency evaluation of these compounds, two murine tumor models, fibrosarcoma (FsaR) and squamous cell carcinoma (SCC VII) were used. The used dose was equal for both substances. The anti-tumor effect of 4 intratumoral injections of thymoquinone and thymohydroquinone at the dose of 5 $\mathrm{mg} / \mathrm{kg}$ was evaluated by comparison of tumor growth kinetics between treated and control animals. This in-vitro study showed that thymoquinone and thymohydroquinone exhibit statistically significant cytotoxic activity $(p<0.01) .{ }^{[112,113]}$

\section{Carminative Action}

A carminative, also acknowledged as carminativum is a herb or preparation that either prevents gas formation in the gastrointestinal tract or facilitates the expulsion of said gas, thereby, combatting flatulence. ${ }^{[114]}$ Carminatives have been shown to decrease lower esophageal pressure, which on the other hand increases the risk of Gastroesophageal reflux disease (GERD) or 'heartburn'. Some studies have reported carminative effects of $N$. sativa as its constituent thymoquinone could protect the gastric mucosa against the injurious effect of absolute alcohol and promote ulcer healing. ${ }^{[14]}$

\section{Neuroprotective Action}

Studies have been conducted on N. sativa to find effects on the central nervous system (CNS). Neuropharmacological activity of $N$. sativa L. extracts was studied and it observed that $N$. sativa possesses the potential to alter the central nervous system (CNS). Furthermore, the neuro-pharmacological activity of $N$. sativa is still under investigation. It has been shown that $N$. sativa causes morphological improvement on toluene-induced nuero-degeneration in the frontal cortex and brain stem. Moreover, the distorted nerve cells in the hippocampus were also absent in N. sativa treated rats. Thus $N$. sativa may indicate its usefulness as a potential treatment on neurodegeneration after chronic toluene exposure in rats. ${ }^{[115,116]}$

\section{Conclusion}

Nigella Sativa is a miraculous herb. Of the traditional remedies, prescriptions of Nigella sativa for the treatment of various diseases are well known since prehistoric era. It has miraculous properties. It has an anti-microbial effect, hepatoprotective effect, anti-diabetic effect, antiinflammatory and analgesic effect, antifertility effect, anthelmintic effect, antioxidant effect, anti-cancerous effect, carminative effect, neuroprotective effect and many more effects. Therapeutic effects of Nigella sativa are thought to be due to nigellone and thymoquinone contents. However, future research is needed for the standardization of the active constituents and their efficacy in human subjects.

\section{References}

1. Haque MM. Inventory and documentation of medicinal plants in Bangladesh. Medicinal Plants Research in Asia, Volume 1: The Framework and Project Workplans. 2004:45.

2. Chopra RN, Chopra IC, Handa KL, Kapoor LD. Indigenous drugs of India Academic publishers. Calcutta-New Delhi. 1982;306.

3. Kirtikar KR, Basu BD. Indian medicinal plants. Indian Medicinal Plants.. 1935.

4. Datta AK, Saha A, Bhattacharya A, Mandal A, Paul R, Sengupta S. Black cumin (Nigella sativa L.)-a review. Journal of plant development sciences. 2012;4(1):1-43.

5. Pruthi JS. Spices and condiments. National Book Trust, India; 1976.

6. List BS. Botanical Society of Britain and Ireland. Archived from the original (xls) on 2015-01-25. Retrieved 2014-1017; 2007.

7. Heiss AG, Oeggl K. The oldest evidence of Nigella damascena L.(Ranunculaceae) and its possible introduction to central Europe. Vegetation history and archaeobotany. 2005 Dec;14(4):562-70.

8. Zohary D, Hopf M. Domestication of plants in the Old World: The origin and spread of cultivated plants in West Asia, Europe and the Nile Valley. Oxford University Press; 2000.

9. Salih B, Sipahi T, Dönmez EO. Ancient nigella seeds from Boyalı Höyük in north-central Turkey. Journal of ethnopharmacology. 2009 Jul 30;124(3):416-20.

10. Malcolm S. The Encyclopedia of herbs and herbalism.

11. Al-Sa'aidi JA, Kareem HM. Pancreatic, hepatic, and renal histopatholological changes in thymoquinone-treated streptozotocin-induced diabetic male rats. AL-Qadisiyah Journal of pure Science. 2018 May 25;23(2):320-31.

12. Al-Jassir MS. Chemical composition and microflora of black cumin (Nigella sativa L.) seeds growing in Saudi Arabia. Food Chemistry. 1992 Jan 1;45(4):239-42.

13. Paarakh PM. Nigella sativa Linn.-A comprehensive review.

14. Naz H. Nigella sativa: the miraculous herb. Pak. J. Biochem. Mol. Biol. 2011;44(1):44-8.

15. Datta AK, Saha A, Bhattacharya A, Mandal A, Paul R, Sengupta S. Black cumin (Nigella sativa L.)-a review. Journal of plant development sciences. 2012;4(1):1-43.

16. Meena SS, Mehta RS, Lal G, Kant K, Sharma YK, Saxena SN, Anwer MM. Essential oil, fatty oil and seed yield of nigella (Nigella sativa L.) as influenced by sowing dates and crop geometry. Indian Journal of Horticulture. 2012;69(4):591-3. 
17. El-Dakhakhny M, Mady N, Lembert N, Ammon HP. The hypoglycemic effect of Nigella sativa oil is mediated by extrapancreatic actions. Planta medica. 2002 May;68(05):465-6.

18. Maqbool M, Fekadu G, Dugassa D, Bekele F, Turi E, Simegnew D. The Pattern of Substance Abuse in the Psychiatry Department of a Tertiary Care of Srinagar Hospital, Jammu and Kashmir, India. Archives of Neuroscience. 2020 Oct 31;7(4).

19. Ahmad A, Husain A, Mujeeb M, Khan SA, Najmi AK, Siddique NA, Damanhouri ZA, Anwar F. A review on therapeutic potential of Nigella sativa: A miracle herb. Asian Pacific journal of tropical biomedicine. 2013 May 1;3(5):337-52.

20. ATTA-UR-RAHMAN AU, Malik S, Hasan SS, Choudhary MI, Ni CZ, Clardy J. Nigellidine-A New Indazole Alkaloid from the Seeds of Nigella sativa. Chemlnform. $1995 \mathrm{Jul}$ 25;26(30):no-.

21. Cheikh-Rouhou S, Besbes S, Lognay G, Blecker C, Deroanne C, Attia H. Sterol composition of black cumin (Nigella sativa L.) and Aleppo pine (Pinus halepensis Mill.) seed oils. Journal of Food Composition and Analysis. 2008 Mar 1;21(2):162-8.

22. Mehta BK, Verma M, Gupta M. Novel lipid constituents identified in seeds of Nigella sativa (Linn). Journal of the Brazilian Chemical Society. 2008;19(3):458-62.

23. Bourgou S, Ksouri R, Bellila A, Skandrani I, Falleh H, Marzouk B. Phenolic composition and biological activities of Tunisian Nigella sativa L. shoots and roots. Comptes Rendus Biologies. 2008 Jan 1;331(1):48-55.

24. Morikawa T, Xu F, Ninomiya K, Matsuda H, Yoshikawa M. Nigellamines A3, A4, A5, and C, new dolabellane-type diterpene alkaloids, with lipid metabolism-promoting activities from the Egyptian medicinal food black cumin. Chemical and pharmaceutical bulletin. 2004;52(4):494-7.

25. Ali Z, Ferreira D, Carvalho P, Avery MA, Khan IA. Nigellidine-4-O-sulfite, the first sulfated indazole-type alkaloid from the seeds of Nigella sativa. Journal of natural products. 2008 Jun 27;71(6):1111-2.

26. Mehta BK, Pandit V, Gupta M. New principles from seeds of Nigella sativa. Natural product research. 2009 Jan 20;23(2):138-48.

27. Ayed $A L$, Talal Z. Long-term effects of Nigella sativa $L$. oil on some physiological parameters in normal and streptozotocin-induced diabetic rats. Journal of Diabetes Mellitus. 2011 Aug 31;2011.

28. Haq A, Remo N, Al-Sedairy ST. Fractionation of black seed (Nigella sativa Linn) proteins by using rotofor. Journal of liquid chromatography \& related technologies. 1996 Feb 1;19(4):593-9.

29. Siong TE, Choo KS, Shahid SM. Determination of calcium in foods by the atomic absorption spectrophotometric and titrimetric methods. Pertanika. 1989;12(3):303-11.

30. Takruri HR, Dameh MA. Study of the nutritional value of black cumin seeds (Nigella sativaL). Journal of the Science of Food and Agriculture. 1998 Mar;76(3):404-10.
31. Al-Yahya MA. Phytochemical studies of the plants used in traditional medicine of Saudi Arabia. Fitoterapia. 1986.

32. Tariq M. Nigella sativa seeds: folklore treatment in modern day medicine. Saudi journal of gastroenterology: official journal of the Saudi Gastroenterology Association. 2008 Jul;14(3):105.

33. Nadkarni KM. Indian Materia Medica Mumbai: Popular Prakashan Pvt.

34. Dar MA, Maqbool M, Ishaq M. MIRACULOUS EFFECTS OF NIGELLA SATIVA L. ON OUR HEALTH.

35. Sharma Y, Bashir S, Irshad M, Gupta SD, Dogra TD. Effects of acute dimethoate administration on antioxidant status of liver and brain of experimental rats. Toxicology. 2005 Jan 5;206(1):49-57.

36. Hanafy MS, Hatem ME. Studies on the antimicrobial activity of Nigella sativa seed (black cumin). Journal of ethnopharmacology. 1991 Sep 1;34(2-3):275-8.

37. Hosseinzadeh H, Fazly Bazzaz BS, Haghi MM. Antibacterial activity of total extracts and essential oil of Nigella sativa L. seeds in mice. Pharmacologyonline. 2007;2:429-35.

38. Chaieb K, Kouidhi B, Jrah H, Mahdouani K, Bakhrouf A. Antibacterial activity of Thymoquinone, an active principle of Nigella sativa and its potency to prevent bacterial biofilm formation. BMC complementary and alternative medicine. 2011 Dec;11(1):1-6.

39. Datta AK, Saha A, Bhattacharya A, Mandal A, Paul R, Sengupta S. Black cumin (Nigella sativa L.)-a review. Journal of plant development sciences. 2012;4(1):1-43.

40. Abdulelah HA, Zainal-Abidin BA. In vivo anti-malarial tests of Nigella sativa (black seed) different extracts. Am J Pharmacol Toxicol. 2007;2(2):46-50.

41. Salem ML. Immunomodulatory and therapeutic properties of the Nigella sativa L. seed. International immunopharmacology. 2005 Dec 1;5(13-14):1749-70.

42. Isik AF, Kati I, Bayram I, Ozbek H. A new agent for treatment of acute respiratory distress syndrome: thymoquinone. An experimental study in a rat model. European journal of cardio-thoracic surgery. 2005 Aug 1;28(2):301-5.

43. Fekadu G, Gamachu B, Mengie T, Maqbool M. Knowledge, attitude of health care professional's towards clinical pharmacy services in Nedjo General Hospital, Western Ethiopia. International Journal. 2019 Jul;5(7):172.

44. Büyüköztürk $S$, Gelincik A, Özşeker F, Genç S, Şavran FO, Kıran B, Yıllar G, Erden S, Aydın F, Çolakoğlu B, Dal M. Nigella sativa (black seed) oil does not affect the T-helper 1 and T-helper 2 type cytokine production from splenic mononuclear cells in allergen sensitized mice. Journal of ethnopharmacology. 2005 Sep 14;100(3):295-8.

45. Zaher KS, Ahmed WM, Zerizer SN. Observations on the biological effects of black cumin seed (Nigella sativa) and green tea (Camellia sinensis). Global Veterinaria. 2008;2(4):198-204.

46. Kalus U, Pruss A, Bystron J, Jurecka M, Smekalova A, Lichius JJ, Kiesewetter H. Effect of Nigella sativa (black seed) on subjective feeling in patients with allergic 
diseases. Phytotherapy Research: An International Journal Devoted to Pharmacological and Toxicological Evaluation of Natural Product Derivatives. 2003 Dec;17(10):1209-14.

47. Dahri AH, Chandio AM, Rahoo AA, Memon RA. Effect of Nigella sativa (kalonji) on serum cholesterol of albino rats. Journal of Ayub Medical College Abbottabad. 2005;17(2).

48. Enomoto $S$, Asano R, Iwahori Y, Narui T, Okada Y, Singab AN, Okuyama T. Hematological studies on black cumin oil from the seeds of Nigella sativa L. Biological and Pharmaceutical Bulletin. 2001;24(3):307-10.

49. Hosseinzadeh $\mathrm{H}$, Parvardeh S. Anticonvulsant effects of thymoquinone, the major constituent of Nigella sativa seeds, in mice. Phytomedicine. 2004 Jan 1;11(1):56-64.

50. Aqel M, Shaheen R. Effects of the volatile oil of Nigella sativa seeds on the uterine smooth muscle of rat and guinea pig. Journal of ethnopharmacology. 1996 May 1;52(1):23-6.

51. Mansi KM. Effects of oral administration of water extract of Nigella sativa on serum concentrations of insulin and testosterone in alloxan-induced diabetic rats. Pakistan Journal of Biological Sciences. 2005;8(8):1152-6.

52. Gilani AH, Aziz N, Khurram IM, Chaudhary KS, lqbal A. Bronchodilator, spasmolytic and calcium antagonist activities of Nigella sativa seeds (Kalonji): a traditional herbal product with multiple medicinal uses. Journal of Pakistan Medical Association. 2001;51(3):115.

53. Zaoui A, Cherrah Y, Alaoui K, Mahassine N, Amarouch $\mathrm{H}$, Hassar M. Effects of Nigella sativa fixed oil on blood homeostasis in rat. Journal of Ethnopharmacology. 2002 Feb 1;79(1):23-6.

54. Sayed-Ahmed MM, Nagi MN. Thymoquinone supplementation prevents the development of gentamicin-induced acute renal toxicity in rats. Clinical and Experimental Pharmacology and Physiology. 2007 May;34(5-6):399-405.

55. Uz E, Bayrak O, Uz E, Kaya A, Bayrak R, Uz B, Turgut FH, Bavbek N, Kanbay M, Akcay A. Nigella sativa oil for prevention of chronic cyclosporine nephrotoxicity: an experimental model. American journal of nephrology. 2008;28(3):517-22.

56. Yaman I, Balikci E. Protective effects of Nigella sativa against gentamicin-induced nephrotoxicity in rats. Experimental and Toxicologic Pathology. 2010 Mar 1;62(2):183-90.

57. Zaoui A, Cherrah Y, Lacaille-Dubois MA, Settaf A, Amarouch $\mathrm{H}$, Hassar M. Diuretic and hypotensive effects of Nigella sativa in the spontaneously hypertensive rat. Therapie. 2000 May 1;55(3):379-82.

58. Yar T, El-Hariri M, El-Bahai MN, Bamosa AO. Effects of Nigella sativa supplementation for one month on cardiac reserve in rats. Indian J Physiol Pharmacol. 2008 Jan 1;52(2):141-8.

59. El-Said SM, Alamri MB, El-Barak AB, Alsogair O. Adsorptive removal of arsenite as (III) and arsenate as (V) heavy metals from waste water using Nigella sativa L. Asian Journal of Scientific Research. 2009;2(2):96-104.

60. Arayne MS, Sultana N, Mirza AZ, Zuberi MH, Siddiqui FA. In vitro hypoglycemic activity of methanolic extract of some indigenous plants. Pak J Pharm Sci. 2007 Oct 1;20(4):268-73.

61. Ramadhan UH, Mohammedali MA, Abood HS. Study the analgesic activity of Nigella sativa L. volatile oil against pain in mice. Journal of Current Pharmaceutical Research. 2011;5(1):36-8.

62. Khalil W, Abdel-Gawad F, Belattar N, Senator A, AbdelWahhab M. Protective effects of Nigella sativa extract against chromium (VI)-induced genotoxicity in Nile tilapia (Oreochromis niloticus) and Zebrafish (Danio rerio). Global Vet. 2011;7:283-93.

63. Tasawar Z, Siraj Z, Ahmad N, Lashari MH. The effects of Nigella sativa (Kalonji) on lipid profile in patients with stable coronary artery disease in Multan, Pakistan. Pakistan journal of nutrition. 2011.

64. Aljabre SH, Randhawa MA, Akhtar N, Alakloby OM, Alqurashi AM, Aldossary A. Antidermatophyte activity of ether extract of Nigella sativa and its active principle, thymoquinone. Journal of Ethnopharmacology. 2005 Oct 3;101(1-3):116-9.

65. Randhawa MA, Alaklobi OM, Ajabre SH, Alqurashi AM, Akhtar N. Thymoquinone, an active principle of Nigella sativa, inhibited Fusarium solani. Pakistan Journal of Medical Research. 2005;44(1):1-3.

66. Malhi BS, Trivedi VP. Vegetable antifertility drugs of India. Quarterly Journal of Crude Drug Research. 1972 Jan 1;12(3):1922-8.

67. Sangi S, Ahmed SP, Channa MA, Ashfaq M, Mastoi SM. A new and novel treatment of opioid dependence: Nigella sativa 500 mg. J Ayub Med Coll Abbottabad. 2008 Apr 15;20(2):118-24.

68. Chaubey MK. Insecticidal activity of Trachyspermum ammi (Umbelliferae), Anethum graveolens (Umbelliferae) and Nigella sativa (Ranunculaceae) essential oils against stored-product beetle Tribolium castaneum Herbst (Coleoptera: Tenebrionidae). African Journal of Agricultural Research. 2007 Nov 30;2(11):596-600.

69. Youssef MM. Effect of feeding Nigella sativa cake on production and reproduction performance of buffaloes. Egyptian Journal of Nutrition and Feeds. 1998;1: 73-85.

70. Osman AM, El-Barody MA. Growth performance and immune response of broiler chicks as affected by diet density and Nigella sativa seeds supplementation. Egypt. Poult. Sci. J. 1999;19:619-34.

71. Mashhadian NV, Rakhshandeh H. Antibacterial and antifungal effects of Nigella sativa extracts against $\mathrm{S}$. aureus, P. aeroginosa and C. albicans. Pak J Med Sci. 2005;21(1):47-52.

72. Hannan A, Saleem S, Chaudhary S, Barkaat M, Arshad MU. Anti bacterial activity of Nigella sativa against clinical 
isolates of methicillin resistant Staphylococcus aureus. J Ayub Med Coll Abbottabad. 2008 Jul;20(3):72-4.

73. Sitara U, Niaz I, Naseem J, Sultana N. Antifungal effect of essential oils on in vitro growth of pathogenic fungi. Pakistan Journal of Botany. 2008 Feb 1;40(1):409.

74. Khan MA, Ashfaq MK, Zuberi HS, Mahmood MS, Gilani $\mathrm{AH}$. The in vivo antifungal activity of the aqueous extract from Nigella sativa seeds. Phytotherapy Research: An International Journal Devoted to Pharmacological and Toxicological Evaluation of Natural Product Derivatives. 2003 Feb;17(2):183-6.

75. Mohideen S, llavarasan R, Sasikala E, Kumaran RT. Hepatoprotective activity of Nigella sativa Linn. Indian journal of pharmaceutical sciences. 2003;65(5):550.

76. Al-Razzuqi RA, Al-Hussaini JA, Al-Jeboori AA. Protective effect of Nigella sativa against carbon tetrachlorideinduced acute liver injury in experimental rabbit models. International Journal of Green Pharmacy (IJGP). 2011;5(3).

77. Michel CG, El-Sayed NS, Moustafa SF, Ezzat SM, Nesseem $\mathrm{DI}$, El-Alfy TS. Phytochemical and biological investigation of the extracts of Nigella sativa L. seed waste. Drug testing and analysis. 2011 Apr;3(4):245-54.

78. Farrag AR. Protective effect of Nigella sativa seeds against lead-induced hepatorenal damage in male rats' Abdel-Razik H. Farrag,"Karam A. Mahdy,'Gamal H. Abdel Rahman and "Mostafa M. Osfor" Departments of Pathology,“'Department of Medical Biochemistry. J. Biol. Sci.. 2007;10(17):2809-16.

79. Danladi J, Abdulsalam A, Timbuak JA, Ahmed SA, Mairiga AA, Dahiru AU. Hepatoprotective effect of black seed (Nigella sativa) oil on carbon tetrachloride (ccl4) induced liver toxicity in adult wistar rats. J Dental Med Sci. 2013;4:56-62.

80. Türkdoğan MK, Ozbek H, Yener Z, Tuncer I, Uygan I, Ceylan E. The role of Urtica dioica and Nigella sativa in the prevention of carbon tetrachloride-induced hepatotoxicity in rats. Phytotherapy Research: An International Journal Devoted to Pharmacological and Toxicological Evaluation of Natural Product Derivatives. 2003 Sep;17(8):942-6.

81. Mathur ML, Gaur J, Sharma R, Haldiya KR. Antidiabetic properties of a spice plant Nigella sativa. Journal of Endocrinology and Metabolism. 2011;1(1):1-8.

82. al-Awadi FA, Fatania HA, Shamte UM. The effect of a plants mixture extract on liver gluconeogenesis in streptozotocin induced diabetic rats. Diabetes Research (Edinburgh, Scotland). 1991 Dec 1;18(4):163-8.

83. Eskander EF, Jun HW, Ibrahim KA, Abdelal WE. Hypoglycemic effect of a herbal formulation in alloxan induced diabetic rats Egypt. J Pharm Sci. 1995;36:253-70.

84. Salama RH. Hypoglycemic effect of lipoic acid, carnitine and Nigella sativa in diabetic rat model. International journal of health sciences. 2011 Jul;5(2):126.

85. Chehl N, Chipitsyna G, Gong Q, Yeo CJ, Arafat HA. Antiinflammatory effects of the Nigella sativa seed extract, thymoquinone, in pancreatic cancer cells. Hpb. 2009 Aug 1;11(5):373-81.

86. Alemi M, Sabouni F, Sanjarian F, Haghbeen K, Ansari S. Anti-inflammatory effect of seeds and callus of Nigella sativa L. extracts on mix glial cells with regard to their thymoquinone content. Aaps Pharmscitech. 2013 Mar;14(1):160-7.

87. El Mezayen R, El Gazzar M, Nicolls MR, Marecki JC, Dreskin SC, Nomiyama H. Effect of thymoquinone on cyclooxygenase expression and prostaglandin production in a mouse model of allergic airway inflammation. Immunology letters. 2006 Jul 15;106(1):7281.

88. Bourgou S, Pichette A, Marzouk B, Legault J. Antioxidant, anti-inflammatory, anticancer and antibacterial activities of extracts from Nigella sativa (black cumin) plant parts. Journal of Food Biochemistry. 2012 Oct;36(5):539-46.

89. Maqbool M, Gani I, Dar MA. Anti-diabetic effects of some medicinal plants in experimental animals: a review. Asian Journal of Pharmaceutical Research and Development. 2019 Feb 15;7(1):66-9.

90. Maqbool M, Dar MA, Gani I, Mir SA. Animal models in diabetes mellitus: an overview. Journal of Drug Delivery and Therapeutics. 2019 Feb 15;9(1-s):472-5.

91. Nikakhlagh S, Rahim F, Aryani FH, Syahpoush A, Brougerdnya MG, Saki N. Herbal treatment of allergic rhinitis: the use of Nigella sativa. American journal of otolaryngology. 2011 Sep 1;32(5):402-7.

92. Malairajan P, Gopalakrishnan G, Narasimhan S, Veni $\mathrm{KJ}$. Analgesic activity of some Indian medicinal plants. Journal of ethnopharmacology. $2006 \mathrm{Jul}$ 19;106(3):425-8.

93. Bashir MU, Qureshi HJ. Analgesic effect of Nigella sativa seeds extract on experimentally induced pain in albino mice. J Coll Physicians Surg Pak. 2010 Jul 1;20(7):464-7.

94. Öberg $F$, Haseeb A, Ahnfelt $M$, Pontén F, Westermark B, El-Obeid A. Herbal melanin activates TLR4/NF-KB signaling pathway. Phytomedicine. 2009 May 1;16(5):47784.

95. Keshri G, Singh MM, Lakshmi V, Kamboj VP. Post-coital contraceptive efficacy of the seeds of Nigella sativa in rats. Indian Journal of Physiology and Pharmacology. 1995 Jan 1;39:59-59.

96. Al-Ali A, Alkhawajah AA, Randhawa MA, Shaikh NA. Oral and intraperitoneal LD50 of thymoquinone, an active principle of Nigella sativa, in mice and rats. J Ayub Med Coll Abbottabad. 2008;20(2):25-7.

97. Ozdemir H, Kara MI, Erciyas K, Ozer HA, Ay S. Preventive effects of thymoquinone in a rat periodontitis model: a morphometric and histopathological study. Journal of periodontal research. 2012 Feb;47(1):74-80.

98. Gayar F, Shazli A. Toxicity of certain plants to Culex pipiens L. larvae (Diptera; Culicidae). Soc Entomol Egypte Bull. 1969.

99. Burits M, Bucar F. Antioxidant activity of Nigella sativa essential oil. Phytotherapy research. 2000 Aug;14(5):323328. 
100. Yoruk O, Gur F, Uyanik H, Yasar M, Mutlu V, Altas E, Baysal E, Taysi S. Antioxidant effects of Nigella sativa in the treatment of experimentally induced rhinosinusitis. Macedonian Journal of Medical Sciences. 2010 Jun 15;3(2):132-7.

101. Al-Othman AM, Ahmad F, Al-Orf S, Al-Murshed KS, Arif Z. Effect of dietary supplementation of Ellataria cardamomum and Nigella sativa on the toxicity of rancid corn oil in Rats. Int J Pharmacol. 2006;2(1):60-5.

102. El Gendy S, Hessien M, Abdel Salam I, Morad M, El-Magraby K, Ibrahim HA, Kalifa MH, El-Aaser AA. Evaluation of the possible antioxidant effects of Soybean and Nigella sativa during experimental hepatocarcinogenesis by nitrosamine precursors. Turkish J Biochem. 2007 Jan 1;32(1):5-11.

103. Sogut B, Çelik I, Tuluce Y. The effects of diet supplemented with the black Cumin (Nigella sativa L.) upon immune potential and antioxidant marker enzymes and lipid peroxidation in broiler chicks.

104. Mariod AA, Ibrahim RM, Ismail M, Ismail N. Antioxidant activity and phenolic content of phenolic rich fractions obtained from black cumin (Nigella sativa) seedcake. Food Chemistry. 2009 Sep 1;116(1):306-12.

105.Jrah Harzallah H, Grayaa R, Kharoubi W, Maaloul A, Hammami M, Mahjoub T. Thymoquinone, the Nigella sativa bioactive compound, prevents circulatory oxidative stress caused by 1, 2-dimethylhydrazine in erythrocyte during colon postinitiation carcinogenesis. Oxidative medicine and cellular longevity. 2012;2012.

106. Randhawa MA, Alghamdi MS. Anticancer activity of Nigella sativa (black seed) - a review. The American journal of Chinese medicine. 2011;39(06):1075-91.

107. Rasool S, Maqbool M. An overview about Hedychium spicatum: A review. Journal of Drug Delivery and Therapeutics. 2019 Feb 15;9(1-s):476-80.

108. Ait Mbarek L, Ait Mouse H, Elabbadi N, Bensalah M, Gamouh A, Aboufatima R, Benharref A, Chait A, Kamal
M, Dalal A, Zyad A. Anti-tumor properties of blackseed (Nigella sativa L.) extracts. Brazilian Journal of Medical and Biological Research. 2007 Jun;40(6):839-47.

109. Musa D, Dilsiz N, Gumushan H, Ulakoglu G, Bitiren M. Antitumor activity of an ethanol extract of Nigella sativa seeds. Biologia, Bratislava. 2004 Nov 1;59(6):735-40.

110. De Azevedo WF, Mueller-Dieckmann HJ, SchulzeGahmen U, Worland PJ, Sausville E, Kim SH. Structural basis for specificity and potency of a flavonoid inhibitor of human CDK2, a cell cycle kinase. Proceedings of the National Academy of Sciences. 1996 Apr 2;93(7):2735-40.

111. Fotsis T, Pepper MS, Aktas E, Breit S, Rasku S, Adlercreutz H, Wähälä K, Montesano R, Schweigerer L. Flavonoids, dietary-derived inhibitors of cell proliferation and in vitro angiogenesis. Cancer research. 1997 Jul 15;57(14):29162921.

112. Ivankovic S, Stojkovic R, Jukic M, Milos M. The antitumor activity of thymoquinone and thymohydroquinone in vitro and in vivo. Experimental oncology. 2006.

113. Mahmoud SS, Torchilin VP. Hormetic/cytotoxic effects of Nigella sativa seed alcoholic and aqueous extracts on MCF-7 breast cancer cells alone or in combination with doxorubicin. Cell biochemistry and biophysics. 2013 Jul;66(3):451-60.

114. El-Abhar HS, Abdallah DM, Saleh S. Gastroprotective activity of Nigella sativa oil and its constituent, thymoquinone, against gastric mucosal injury induced by ischaemia/reperfusion in rats. Journal of ethnopharmacology. 2003 Feb 1;84(2-3):251-8.

115. Al-Naggar TB, Gomez-Serranillos MP, Carretero ME, Villar AM. Neuropharmacological activity of Nigella sativa L. extracts. Journal of ethnopharmacology. 2003 Sep 1;88(1):63-8.

116. Bano F, Wajeeh M, Baig N, Naz H, Akhtar N. Antiobesity, antihyperlipidemic and hypoglycemic effects of the aqueous extract of Nigella Sativa seeds (Kalongi). J Biochem Mol Biol. 2009;42(4):136-40. 